\title{
Anesthetic Managements of Cesarean Section in Parturient Diagnosed with Placenta Previa, Retrospective Analysis of 240 Consecutive Cases in Aswan University Hospital Cross Sectional Study
}

\author{
Ayman Eldemrdash*, Nagwa Gamaledeen and Amir AbouZkry El-Sayed \\ Department of Anesthesiology, Aswan University, Egypt
}

Submission: October 01, 2017; Published: November 21, 2017

*Corresponding author: Ayman Eldemrdash, Department of Anesthesiology, I.C.U Department, Faculty of Medicine, Aswan University, Egypt, Tel: 00201001296116; Email: aymaneldemrdash@yahoo.com

\begin{abstract}
Background: Anesthetic managements for cesarean section in parturient diagnosed with placenta previa still controversial.

Objectives: choice of anesthesia in these parturient to assessment factors correlated with the techniques and their outcomes.

Methods: Retrospective analysis of patients with placenta previa and cesarean section at Aswan university Hospital. Perioperative anesthetic and complication data were collected using a structured collection form. Univariate analysis and multivariate logistic regression were used. $\mathrm{P}<0.05$ was considered significant.

Results: Among 7,237 deliveries from 1 July, 2014 to 30 April, 2017, there were 240 cesarean sections in diagnosed cases of placenta previa. Cesarean deliveries (192cases) were performed under spinal anesthesia $(80 \%)$ and (5cases) epidural anesthesia (2\%), and if the effects spinal anesthesia dissipated, general anesthesia (2.5\%) 6 cases. (36 cases) were performed under general anesthesia $(15.5 \%)$. Among 20 cases of cesarean hysterectomy, 12 patients (60\%) received regional anesthesia, while 1 of 12 of a group with regional anesthesia needed conversion to general anesthesia. However, 2 of 8 patients with planned cesarean hysterectomy underwent general anesthesia. While, 2 of 12 patients with planned cesarean hysterectomy underwent regional anesthesia. There was no serious anesthesia-related complication. Factors related to general anesthesia were: a higher American Society of Anesthesiologists (ASA) physical status OR 2.7 (95\% CI 1.7-4.3) P < 0.001; anterior site of placenta OR 1.8 (95\% CI 1.1-3.2) P $=0.025$; presentation with bleeding or $1.8(95 \%$ CI 1.0-3.1) $\mathrm{P}=0.033$; pack red cell transfusion or 3.4 (95\% CI 2.0-5.7) $\mathrm{P}<0.001$ and heart rate $>125$ bpm OR $5.6(95 \%$ CI 1.5-214) $\mathrm{P}=0.01$.
\end{abstract}

Conclusions: Regional anesthesia and general anesthesia are safe. Most parturient received regional anesthesia.

Keywords: Cesarean delivery; placenta previa; Complication; Neuraxial anesthesia; Choice of anesthesia; Spinal anesthesia

Abbreviations: CI: Confidence Interval; GA: General Anesthesia; RA: Regional Anesthesia; ASA: Society of Anesthesiologists

\section{Introduction}

Placenta previa, is the most common cause of extensive hemorrhage in obstetric patients and can result in maternal and/or fetal morbidity and mortality [1,2]. Its incidence is 4.8 per 1000 deliveries with a mortality rate of $0.03 \%$ [3]. The ideal anesthetic technique for cesarean delivery still controversial. General anesthesia is believed to be preferable for this group of patients and stander method [4]. There is also evidence that a majority of anesthesiologists consider using regional anesthesia mostly spinal for placenta previa [4-6]. Obstetric complications have recently been highlighted by the mass media in Aswan. This situation in our area dramatically increased due to increase the incidence of cesarean sections and considers the referral of high risk obstetric patients for medical services to tertiary care hospitals. Our institution developed guidelines for anesthesia for placenta previa, but technique was left to the decision of the individual anesthesiologist. We performed a retrospective analysis of these cases to investigate factors correlating with choice of anesthetic technique for cesarean delivery and their outcomes.

\section{Methods}

This study was approved by our institutional ethics committee and written informed consent. We investigated demographic, obstetric, and anesthetic data of all parturient with placenta previa (including placental adherence such as placenta accreta, increta and percreta) who received anesthesia 
for cesarean section. We extracted data from the hospital's computerized database, hand-written labor ward register and the obstetric operating theatre register using a structured case-record form. For each patient, the following information was recorded: gestation, previous cesarean delivery, type of placenta previa, position of placenta (from ultrasound reports or description at surgery), emergency or elective (as defined by the obstetrician), clinical presentation, preoperative vital signs, preoperative hematocrit, estimated blood loss during surgery, intraoperative and postoperative (within 24h) blood transfusions, intraoperative administration of ephedrine or methylergometrine (Methergine), postoperative hematocrit, duration of anesthesia, admission to intensive care unit, length of hospital stay, and main anesthetic techniques for cesarean delivery.

Main anesthetic techniques were classified into 2 groups:

i. A general anesthesia (GA) group: including general anesthesia and general anesthesia after failed or inadequate spinal anesthesia.

ii. A regional anesthesia (RA) group: including spinal anesthesia, epidural anesthesia, and general anesthesia after the effects of spinal anesthetic had dissipated.

Data were analyzed using SPSS. Factors potentially associated with choice of anesthesia were assessed by using a t test (for continuous data) and Chi-square test or Fisher's exact test (for categorical data). Multivariate logistic regression with a forward stepwise approach was then used to identify the magnitude of association in term of crude odds ratio with a $95 \%$ confidence interval $(95 \% \mathrm{CI})$. In all cases, two-tailed tests were performed, and $\mathrm{P}<0.05$ was considered statistically significant.

\section{Results}

The demographic data of parturient in the GA and RA groups were comparable except for body weight $(\mathrm{P}=0.03)$. The proportion of patients who underwent emergency cesarean section in the GA group (78.6\%) was higher than that in the RA group (61.7\%); $\mathrm{P}=0.004$. Univariate analysis of the preanesthetic characteristics of the patients is shown in Table 1. During the 3-year study period, there were 7,237 deliveries in our institution and 240 (3.31\%) consecutive parturient with a diagnosis of placenta previa who underwent cesarean delivery. 30 cases $(12.5 \%)$ parturient received general anesthesia, and $6(2.5 \%)$ parturients received general anesthesia after failure or inadequate spinal blockade and were classified in the general anesthesia (GA) group. In the regional anesthesia (RA) group, there were $192(80.0 \%)$ parturient who received spinal anesthesia, 5 (2\%) parturient who received epidural anesthesia, and $6(2.5 \%)$ parturient who received spinal anesthesia throughout with subsequent induction of general anesthesia.

Table 1: Univariate analysis of demographic and pre-anesthetic characteristics $(n=240)$.

\begin{tabular}{|c|c|c|c|c|c|c|}
\hline \multirow{2}{*}{ S.No } & & \multicolumn{2}{|c|}{ General Anesthesia } & \multicolumn{2}{|c|}{ Regional Anesthesia } & \multirow{2}{*}{ P. value } \\
\hline & & n. & $\%$ & n. & $\%$ & \\
\hline 1 & $\operatorname{Age}(y)$ & 36 & $33.1 \pm 4.6$ & 204 & $32.7 \pm 4.8$ & .52 \\
\hline 2 & Height $(\mathrm{cm})$ & 36 & $157.4 \pm 5.6$ & 204 & $157.3 \pm 5.4$ & \\
\hline 3 & Weight(kg) & 36 & $63.5 \pm 10.4$ & 204 & $65.9 \pm 9.3$ & $.03^{*}$ \\
\hline 4 & $\begin{array}{c}\text { Pre-anesthetic } \\
\text { Systolic Pressure }\end{array}$ & 36 & $126.1 \pm 17.5$ & 204 & $121.8 \pm 14.4$ & $.036^{*}$ \\
\hline 5 & $\begin{array}{l}\text { Gestational } \\
\text { Age(wk.) }\end{array}$ & 36 & $33.4 \pm 4.6$ & 204 & $36.5 \pm 2.6$ & $<.001^{*}$ \\
\hline 6 & \multicolumn{6}{|c|}{ ASA Physical Status } \\
\hline & I & 21 & $59.5 \%$ & 171 & $83.9 \%$ & \multirow{4}{*}{$<.001^{*}$} \\
\hline & II & 10 & $31 \%$ & 32 & $15.7 \%$ & \\
\hline & III & 4 & $8.3 \%$ & 1 & $4 \%$ & \\
\hline & IV & 1 & $1.2 \%$ & 0 & $0 \%$ & \\
\hline \multirow[t]{3}{*}{7} & \multicolumn{6}{|c|}{ Surgical Status } \\
\hline & Elective & 10 & $21.4 \%$ & 78 & $38.3 \%$ & \multirow{2}{*}{$.004^{*}$} \\
\hline & Emergency & 28 & $78.6 \%$ & 124 & $61.7 \%$ & \\
\hline \multirow[t]{6}{*}{8} & \multicolumn{6}{|c|}{ Presentation } \\
\hline & Labor pain & 2 & $4.8 \%$ & 22 & $10 \%$ & \multirow{5}{*}{$.008^{*}$} \\
\hline & Bleeding & 22 & $61.9 \%$ & 90 & $42.9 \%$ & \\
\hline & Contraction & 2 & $3.6 \%$ & 7 & $2.7 \%$ & \\
\hline & No symptoms & 7 & $20.2 \%$ & 78 & $3.7 \%$ & \\
\hline & $\begin{array}{l}\text { Labor pain- } \\
\text { contraction }\end{array}$ & 2 & $3.6 \%$ & 3 & $.8 \%$ & \\
\hline
\end{tabular}




\begin{tabular}{|c|c|c|c|c|c|c|}
\hline & $\begin{array}{l}\text { Bleeding- } \\
\text { contraction }\end{array}$ & 1 & $2.6 \%$ & 3 & $.8 \%$ & \\
\hline & $\begin{array}{l}\text { Bleeding-labor } \\
\text { pain-contraction }\end{array}$ & 0 & $1.2 \%$ & 1 & $.2 \%$ & \\
\hline \multirow[t]{5}{*}{9.} & \multicolumn{6}{|c|}{ Gravidity } \\
\hline & 1 & 9 & $25 \%$ & 72 & $35.1 \%$ & \multirow{4}{*}{.199} \\
\hline & 2 & 15 & $41.7 \%$ & 74 & $36.6 \%$ & \\
\hline & 3 & 10 & $26.2 \%$ & 39 & $19.2 \%$ & \\
\hline & $>3$ & 3 & $7.1 \%$ & 18 & $9 \%$ & \\
\hline 10. & Previous C.S & 10 & $28.6 \%$ & 37 & $18.3 \%$ & $.057 *$ \\
\hline
\end{tabular}

Two hundred and four of 240 (84.5\%) parturient received in the RA group. However, there were 2 patients with planned regional anesthesia and were categorized in the RA group during cesarean hysterectomy, while 6 patients (50\%) received the retrospective data collection period (July1,2014 to April 30, general anesthesia. Among these, 4 of 12 were associated with 2017), and the rates were not statistically significantly different preoperative diagnosis of placental adherence and 6 of 10 cases $(\mathrm{P}=0.273)$. In the database, there were 20 cases $(8.33 \%)$ of were associated with frank antenatal bleeding. Details of choices hysterectomy and12 cases (5\%) of abnormal placentation of anesthesia among the subgroup of patients with hysterectomy (placenta accreta, placenta per creta, or placenta increta). 12 and/or placental adherence are shown in Table 2. patients undergoing hysterectomy (60\% of 20 cases) and were

Table 2: Anesthetic techniques used for patients with placenta previa undergoing cesarean delivery.

\begin{tabular}{|c|c|c|c|c|c|c|c|}
\hline \multirow[b]{2}{*}{ S. No } & & \multicolumn{2}{|c|}{ G.A Group } & \multicolumn{3}{|c|}{ R.A Group } & \multirow[b]{2}{*}{ Total } \\
\hline & & G.A & $\begin{array}{c}\text { G.A Because of } \\
\text { Failed S.A } \\
\end{array}$ & S.A & S.A Dissipated & Epidural & \\
\hline 1 & Placenta previa & $30(12.40 \%)$ & $6(2.50 \%)$ & 194(81\%) & $6(2.30 \%)$ & $5(1.80 \%)$ & $240(100 \%)$ \\
\hline \multirow[t]{3}{*}{2} & Hysterectomy & $8(39.10 \%)$ & $0.5(2.20 \%)$ & $7(32.60 \%)$ & $5(23.90 \%)$ & $0.5(2.20 \%)$ & $20(100 \%)$ \\
\hline & $\begin{array}{c}\text { Unplanned } \\
\text { cesarean } \\
\text { hysterectomy }\end{array}$ & $5(33.30 \%)$ & $0.5(3 \%)$ & $5(33.30 \%)$ & $4(27.70 \%)$ & $0.5(3 \%)$ & $15(100 \%)$ \\
\hline & $\begin{array}{c}\text { Planned } \\
\text { cesarean } \\
\text { hysterectomy }\end{array}$ & $2(50 \%)$ & $0(0 \%)$ & $1(25 \%)$ & $1(25 \%)$ & $0(0 \%)$ & $5(100 \%)$ \\
\hline 3 & $\begin{array}{c}\text { Placenta } \\
\text { adherence }\end{array}$ & $3(27.60 \%)$ & $1(3.40 \%)$ & $5(41.40 \%)$ & $3(27.60 \%)$ & $0(0 \%)$ & $12(100 \%)$ \\
\hline-- & $\begin{array}{c}\text { Placenta } \\
\text { adherence } \\
\text { without } \\
\text { hysterectomy }\end{array}$ & $1(25 \%)$ & $0(0 \%)$ & $3(75 \%)$ & $0(0 \%)$ & $0(0 \%)$ & $4(100 \%)$ \\
\hline-- & $\begin{array}{c}\text { Placenta } \\
\text { adherence with } \\
\text { hysterectomy }\end{array}$ & $2(25 \%)$ & $1(0 \%)$ & $2(75 \%)$ & $3(0 \%)$ & $0(0 \%)$ & $8(100 \%)$ \\
\hline
\end{tabular}

Table 3: Univariate analysis of placental, intraoperative and postoperative characteristics $(n=240)$.

\begin{tabular}{|c|c|c|c|c|c|c|}
\hline \multirow[t]{2}{*}{ S.No } & & \multicolumn{2}{|c|}{ General Anesthesia } & \multicolumn{2}{|c|}{ Regional Anesthesia } & \multirow{2}{*}{$\begin{array}{c}P \\
\text { Value }\end{array}$} \\
\hline & & $\mathbf{N}$ & $\%$ & $\mathbf{N}$ & $\%$ & \\
\hline \multirow[t]{5}{*}{1} & \multicolumn{6}{|c|}{ Types of placenta Previa } \\
\hline & Low lying. & 5 & $11.90 \%$ & 60 & $29.50 \%$ & \\
\hline & Marginal & 1 & $3.60 \%$ & 13 & $6.30 \%$ & \\
\hline & Partialis & 1 & $3.60 \%$ & 18 & $8.60 \%$ & \\
\hline & Totalis & 29 & $81 \%$ & 113 & $55.60 \%$ & $<.001^{*}$ \\
\hline \multirow[t]{3}{*}{2} & \multicolumn{6}{|c|}{ Placental Site } \\
\hline & Anterior & 15 & $40.50 \%$ & 58 & $28.50 \%$ & \\
\hline & Posterior & 18 & $50 \%$ & 138 & $67.80 \%$ & $.002^{*}$ \\
\hline
\end{tabular}


Journal of Anesthesia \& Intensive Care Medicine

\begin{tabular}{|c|c|c|c|c|c|c|}
\hline & Anterior+Posterior & 3 & $9.50 \%$ & 8 & $3.80 \%$ & \\
\hline \multirow[t]{5}{*}{3} & \multicolumn{6}{|c|}{ Placental Adherence } \\
\hline & No & 31 & $89.30 \%$ & 196 & $96.20 \%$ & $.012^{*}$ \\
\hline & Accreta & 2 & $4.80 \%$ & 5 & $2.70 \%$ & \\
\hline & Increta & 2 & $4.80 \%$ & 2 & $0.80 \%$ & \\
\hline & Percreta & 1 & $1.20 \%$ & 1 & $0.20 \%$ & \\
\hline 4 & $\begin{array}{c}\text { Cesarean } \\
\text { Hysterectomy }\end{array}$ & 8 & $22.60 \%$ & 12 & $5.60 \%$ & $<.001^{*}$ \\
\hline \multirow[t]{4}{*}{5} & \multicolumn{6}{|c|}{ Number of Patient Receiving } \\
\hline & Blood Transfusion & 22 & $61.90 \%$ & 44 & $21.50 \%$ & $<.001^{*}$ \\
\hline & Platelets & 1 & $6 \%$ & 1 & $0.40 \%$ & $.001 *$ \\
\hline & FFP & 7 & $17.90 \%$ & 7 & $3.60 \%$ & $<.001^{*}$ \\
\hline 6 & $\begin{array}{c}\text { Apgar } \\
\text { score<7at1min. }\end{array}$ & 15 & $40.50 \%$ & 12 & $6.10 \%$ & $<.001^{*}$ \\
\hline 7 & $\begin{array}{c}\text { Apgar score }<7 \text { at } \\
5 \mathrm{~min}\end{array}$ & 4 & $11.30 \%$ & 4 & $1.70 \%$ & $<.001^{*}$ \\
\hline \multirow[t]{4}{*}{8} & \multicolumn{6}{|c|}{ Number of Patient Receiving } \\
\hline & Ephedrine & 6 & $16.70 \%$ & 135 & $66.30 \%$ & $.001^{*}$ \\
\hline & $\begin{array}{c}\text { Amount of } \\
\text { ephedrine (mg) }\end{array}$ & 6 & $14.6 \pm 13.6$ & 135 & $15.8 \pm 10.1$ & 0.675 \\
\hline & Methargine & 5 & $13 \%$ & 41 & $20.10 \%$ & 0.176 \\
\hline 9 & $\begin{array}{c}\text { Duration of } \\
\text { anesthesia(min) }\end{array}$ & 36 & $78.9 \pm 46.9$ & 200 & $59.7 \pm 27.8$ & $.002 *$ \\
\hline 10 & $\begin{array}{l}\text { Estimated blood } \\
\text { loss }(\mathrm{ml})\end{array}$ & 36 & $1609.7 \pm 1684.4$ & 198 & $1160.2 \pm 1104.2$ & $.02^{*}$ \\
\hline 11 & $\begin{array}{l}\text { Intraoperative } \\
\mathrm{SP}<70 \mathrm{mmhg}\end{array}$ & 1 & $3.60 \%$ & 82 & $40 \%$ & $.02^{*}$ \\
\hline 12 & $\begin{array}{l}\text { Intraoperative } \\
\mathrm{HR}>125 \mathrm{bpm}\end{array}$ & 3 & $8.30 \%$ & 2 & $1 \%$ & 1 \\
\hline 13 & $\begin{array}{c}\text { Intraoperative } \\
\mathrm{HR}<45 \mathrm{bpm}\end{array}$ & 0 & $0 \%$ & 1 & $0.20 \%$ & 1 \\
\hline 14 & Postoperative Hct $\%$ & 36 & $30.3 \pm 5.4$ & 200 & $32.5 \pm 4.8$ & $.001^{*}$ \\
\hline 15 & $\begin{array}{c}\text { Postoperative } \\
\text { Hct }<30 \%\end{array}$ & 15 & $40.90 \%$ & 38 & $18.80 \%$ & $<.001^{*}$ \\
\hline
\end{tabular}

Types of placenta previa $(\mathrm{P}<0.001)$, placental site or location $(\mathrm{P}=0.002)$, and placental adherence $(\mathrm{P}=0.012)$ were significantly different factors between the GA and RA groups in the univariate analysis. Duration of anesthesia of patients in the GA and the RA groups were $78.9 \pm 46.9 \mathrm{~min}$ and $59.4 \pm 27.8 \mathrm{~min}$ respectively ( $\mathrm{P}=0.002$ ). The estimated blood loss in patients from the G.A. group was $1609.8 \pm 1684.4 \mathrm{~mL}$, which was higher than average of the R.A. group of $1160.2 \pm 1104.2 \mathrm{~mL}(\mathrm{P}=0.02)$. Six patients $(16.7 \%)$ in the GA group required administration of ephedrine compared with 135 (66.3\%) patients in the RA group; $(\mathrm{P}=0.001)$. The proportion of patients receiving packed red cell, fresh frozen plasma, or platelet transfusion was significantly higher in the GA group than in the RA group. The proportion of Apgar score was $<7$ at $1 \mathrm{~min}$, at $5 \mathrm{~min}$, the proportion of patients with a postoperative hematocrit $<30 \%$ of the GA group was also significantly higher than in the RA group. Details of the intraoperative and postoperative characteristics between the 2 groups are shown in Table 3.
When applying multivariate analysis, the factors associated with a choice of general anesthesia compared with regional anesthesia were identified:

1. ASA physical status $(\mathrm{P}<0.001)$

2. Clinical presentation with bleeding $(\mathrm{P}=0.033)$

3. Anterior site of placenta $(\mathrm{P}=0.025)$

4. Receiving packed red cell transfusion $(\mathrm{P}=<0.001)$

5. Intraoperative heart rate higher than 125 beats per $\min (\mathrm{P}=0.01)$ as shown in Table 4 .

There were no anesthetic problems (Tables $2 \& 3$ ) and no major anesthesia related complications. However, there was one case of maternal mortality, patients receiving spinal anesthesia. The case was in a $34 \mathrm{y}$-old parturient, scheduled for elective cesarean delivery. The anesthesiologist performed an uneventful spinal anesthesia, later on still prolonged hemorrhage necessitated hysterectomy. Induction of general anesthesia was 
performed during the hysterectomy. Maternal fatality occurred after massive hemorrhage with massive blood transfusion lead to disseminated intravascular coagulopathy hypothermia and acidosis [7].

Table 4: Factors related to general anesthesia for patient diagnosed with placenta previa undergoing cesarean delivery (multivariate analysis).

\begin{tabular}{|c|c|c|c|}
\hline Factors & Adjusted OR 95\% & Confident Interval & $P$ value \\
\hline \multicolumn{4}{|c|}{ American Society of Anesthesiologists } \\
\hline Physical Status & 2.7 & 1.74 .3 & $<0.001^{*}$ \\
\hline Bleeding Presentation & 1.8 & 1.03 .1 & $0.033^{*}$ \\
\hline Anterior site of Placenta & 1.8 & 1.13 .2 & $0.025^{*}$ \\
\hline $\begin{array}{l}\text { Anterior + Posterior site of } \\
\text { placenta }\end{array}$ & 2.2 & 0.86 .0 & 0.102 \\
\hline Heart rate > 125 bpm & 5.6 & 1.521 .4 & $0.011^{*}$ \\
\hline Packed red cell Transfusion & 3.4 & 2.05 .7 & $<0.001^{*}$ \\
\hline
\end{tabular}

\section{Discussion}

Recent, widespread use of ultrasound has facilitated early diagnosis of placenta previa. The present study revealed the incidence of placenta previa of 33 per 1000 in our institution; this is higher than the incidence of 4.8 per 1000 in the United States [3].This high incidence might be because of increasing referral of high risk patients to our hospital and increase rates of C.S in last times. In placenta previa and ablatio placenta that are the causes of antepartum haemorrhage, the choice of anaesthesia for caesarean section requires care. In high risk of massive bleeding, general anaesthesia is usually recommended for a patient who has more than $1500 \mathrm{~mL}$ of vaginal bleeding, more than 4 gdL-1 of haemoglobin decrease and for who required more than 4 units of acute blood transfusion (11.13). There was no significant difference between patients receiving regional anesthesia or general anesthesia between the retrospective and prospective data collection periods. The majority of parturients $(84.5 \%)$ with diagnosis of placenta previa received regional anesthesia; particularly spinal anesthesia, while only $15.5 \%$ received general anesthesia. Another 13 (2.3\%) parturients received general anesthesia because of inadequate or failed spinal anesthesia. Therefore, the present study showed that regional anesthesia was the anesthetic technique of choice for $84.5 \%$ of parturients. Most anesthesiologists prefer providing regional anesthesia for cesarean delivery, whereas others prefer general anesthesia in all circumstances from the start $[4,8,9]$.

McShane et al. [1] In a retrospective review of 147 cases of placenta previa, only a quarter of cases received regional anesthesia (25\%). There were no complications associated with the anesthetic technique [1]. Parekh et al. [5] in a retrospective review also revealed that regional anesthesia was used in $60 \%$ of cases as in our study [5]. Arcario et al. [10] suggested that regional anesthesia is contraindicated even in cases of simple placenta accreta [10]. Combined spinal epidural anesthesia has also been suggested as anesthetic technique for placenta previa [11]. There were subgroups of 20 cases (8.3\%) of cesarean hysterectomy and 12 cases (5\%) of placenta adherence. Similar to other studies, the majority of hysterectomies were because of abnormal placentation and increased blood loss [12-15].

The present study found that attending anesthesiologists in our institution chose regional anesthesia for cesarean delivery in $60 \%$ of parturients with hysterectomy (20 cases of cesarean hysterectomy, 12 patients (60\%) received regional anesthesia) and $66.6 \%$ of parturients placental adherence (12 cases of placental adherence, 8 patients $(66.6 \%)$ received regional anesthesia). While the diagnosis of abnormal placentation cannot always be made by ultrasound, most placenta adherence in the present study was diagnosed intraoperatively. However, the attending anesthesiologists chose general anesthesia as main technique in elective cesarean hysterectomy is probably because of prolonged surgery, hemodynamic instability from massive blood loss, and patients discomfort However, 2 of 8 patients with planned cesarean hysterectomy underwent general anesthesia. While, 2 of 12 patients of placental adherence with planned cesarean hysterectomy underwent regional anesthesia. Chestnut \& Redick [16] reported 25 cases of placenta previa using continuous epidural anesthesia for elective hysterectomy. While $28 \%$ of patients required intraoperative induction of general anesthesia [17].

In the univariate analysis, lower gestational age might be the explanation of significant lower body weight of parturients in the GA group. Moreover, there were a higher proportion of patients with a higher class of ASA physical status and emergency surgical status in the GA group. There were also several var placenta previa iables which were significantly different only in univariate analysis, but not in multivariate analysis, such as the types of placenta previa, presence of placental adherence, cesarean hysterectomy, number of patients receiving ephedrine, and number of newborns with an Apgar score $<7$ at 1 and 5 min. Other factors significant only in the univariate analysis level were a higher postoperative hematocrit, lower estimated maternal blood loss, and less patients receiving packed red cell, fresh frozen, and platelet transfusion. A Cochrane systematic review of anesthesia for cesarean delivery showed that women 
who had neuraxial anesthesia were found to have a significantly lower difference between pre- and postoperative hematocrit, lower estimated blood loss, but have no significant difference in terms of neonatal Apgar score of $<6$ at 1 and 5 min [18].

In the multivariate analysis the significant variables were ASA physical status, clinical presentation of bleeding, anterior site of placenta, intraoperative heart rate $>125 \mathrm{bpm}$, and transfusion of packed red cells. Factors related to general anesthesia, the ASA physical status was a significant $(\mathrm{P}<0.001)$. Anesthesiologists are 2.7 times more likely to choose general anesthesia when the ASA physical status of parturients are higher. Many studies suggest that general anesthesia is the preferable choice of anesthetic technique in high risk patients $[18,19]$. Moreover, there might be a bias toward general anesthesia in patients with coexisting medical conditions $[20,21]$. The present study demonstrated that general anesthesia was preferable with an adjusted odds ratio of 1.8 when the clinical presentation of patients was associated with bleeding. Anterior site of placenta related to a 1.8-fold increase in receiving general anesthesia. The orientation of placenta to the anterior uterine wall and patient status are factors that should be considered when choosing the anesthetic for parturients with placenta previa [22].

Patients in the GA group were more likely to have intraoperative heart rates $>125 \mathrm{bpm}$ (with an adjusted odds ratio of 5.6) and to receive packed red cell transfusion (with an adjusted odds ratio of 3.3). During light general anesthesia, the sympathetic reflex relates to tachycardia. In animal studies, regional anesthesia caused slower heart rates, greater stroke volume, higher arterial $\mathrm{pH}$, higher bicarbonate concentration, and lower catecholamine concentrations than general anesthesia [23]. The present study also showed an association between GA and higher frequency of blood transfusion. The possible explanations were selection bias for GA, which was frequently chosen for patients with an anterior placental site and presentation of bleeding. Hypotension was considered the most frequent side effect or complication related to regional anesthetic technique, particularly spinal anesthesia. However, hypotension can be controlled and did not lead to major adverse outcomes. There was no mortality and other serious complication related to the choice of anesthesia. There are some limitations to the present study. First, this retrospective analysis was a non randomized, unblinded study that may be subject to some selection or observer bias. Second, there were some incomplete data because of the retrospective-cohort data collection. Third, the results of the present study represent only one tertiary referral center $[24,25]$.

\section{Conclusion}

Most parturients in the present study received spinal anesthesia. Both neuraxial anesthesia and general anesthesia are safe anesthetic techniques for cesarean delivery in parturients diagnosed with placenta previa. General anesthesia correlated with intraoperative tachycardia $(>125 \mathrm{bpm})$ and higher frequency of packed red cell transfusion. High ASA physical status, presentation of antepartum bleeding and anterior site of placenta is preanesthetic factors favoring general anesthesia in this group of patients.

\section{References}

1. McShane PM, Heyl PS, Epstein MF (1985) Maternal and perinatal morbidity resulting from placenta previa. Obstet Gynecol 65(2):176182.

2. Chestnut DH, Dewan DM, Redick LF, Caton D, Spielman FJ (1989) Anesthetic management for obstetric hysterectomy: a multiinstitutional study. Anesthesiology 70(4): 607-610.

3. Iyasu S, Saftlas AK, Rowley DL, Koonin LM, Lawson HW (1983) The epidemiology of placenta previa in the United States 1979 through 1987. Am J Obstet Gynecol 168(5): 1424-1429.

4. Bonner SM, Haynes SR, Ryall D (1995) The anaesthetic management of Caesarean section for placenta previa: a questionnaire survey. Anaesthesia 50(11): 992-994.

5. Parekh N, Husaini SWU, Russel IF (2000) Caesarean section for placenta praevia: a retrospective study of anaesthetic management. $\mathrm{Br}$ J Anaesth 84(6): 725-730.

6. Hong JY, Jee YS, Yoon HJ, Kim SM (2003) Comparison of general and epidural anesthesia in elective cesarean section for placenta previa totalis: maternal hemodynamics, blood loss and neonatal outcome. Int J Obstet Anaesth 12(1): 12-16.

7. Charuluxananan $S$, Thienthong S, Rungreungvanich $M$, Chanchayanon $\mathrm{T}$, Chinachoti T, et al. (2008) Cardiac arrest after spinal anesthesia in Thailand: a prospective multicenter registry of 40271 anesthetics. Anesth Analg 107(5): 1735-1741.

8. Pell WJ (1996) A survey of the anaesthetic management of patients presenting for Caesarean section with high risk obstetric conditions. Int J Obstet Anaesth 5: 219-220.

9. Plumer MH, Rottman R (1996) How anesthesiologists practice obstetric anesthesia. Responses of practicing obstetric anesthesiologists at the 1993 meeting of the Society for Obstetric Anesthesia and Perinatology. Reg Anesth 21(1): 49-60.

10. Arcario T, Greene M, Ostheimer GW, Datta S, Naulty JS (1989) Risks of placenta previa/accreta in patients with previous Caesarean deliveries. Anesthesiology 69 (Suppl 3A): A659.

11. Tsen LC (2009) Antepartum and postpartum hemorrhage. In: Chestnut DH et al. (Eds.), Chestnut's Obstetric Anesthesia Principles and Practice. ( $\left.2^{\text {nd }} e d n\right)$, Mosby Elsevier, Philadelphia, London, pp. 662-682.

12. Collis R, Garry M (2001) CSE is the regional anaesthetic technique of choice for placenta praevia. Int J Obstet Anesth 10(3): 252-253.

13. Avery DM (2009) Obstetric emergencies. Am J Clin Med 6(2): 42-47.

14. Kwee A, Bots ML, Visser GH, Bruinse HW (2008) Emergency perioperative hysterectomy: a prospective study in the Netherlands. Eur J Obstet Gynecol Reprod Biol 124(2): 187-192.

15. Muench MV, Baschat AA, Oyelese Y, Kush MI, Mighty HE, et al. (2008) Gravid hysterectomy: a decade of experience at an academic referral centre. J Reprod Med 53(4): 271-278.

16. Chestnut DH, Redick LF (1985) Continuous epidural anesthesia for elective hysterectomy. South Med J 78(10): 1168-1169, 1173.

17. Selo-Ojeme DO, Bhattacharjee P, Izuwa-Njoku NF, Kader RA (2005) Emergency peripartum hysterectomy in a tertiary London Hospital. Arch Gynecol Obstet 271(2): 154-159.

18. Wright JD, Bonanno C, Shah M, Gaddipati S, Devine P (2010) Peripartum Hysterectomy. Obstet Gynecol 116(6): 429-433. 
19. Afolabi BB, Lesi FEA, Merah NA (2006) Regional versus general anesthesia for caesarean section. Cochrane Database Sys Rev 10 CD004350.

20. Sprung J, Warner ME, Contreras MG, Schroeder DR, Beighley CM, et al. (2003) Predictors of survival following cardiac arrest in patients undergoing noncardiac surgery: a study of 518,294 patients at a tertiary center. Anesthesiology 99(2): 259-269.

21. Aubas S, Biboulet P, Daures JP, du Cailar J (1991) [Incidence and etiology of cardiac arrest occurring during the peroperative period and in the recovery room. Apropos of 102,468 anesthesia cases]. Ann Fr Anesth Reanim 10(5): 436-442.

22. Braz LG, Modolo NSP, Nascimento JP, Bruschi BAM, Castiglia YMM, et al (2006) Perioperative cardiac arrest: a study of 53718 anesthetics over a 9 yr from a Brazilian teaching hospital. Br J Anaesth 96(5): 569-575.

This work is licensed under Creative Commons Attribution 4.0 License

DOI: $10.19080 / J A I C M .2017 .04 .555637$
23. Kyokong O, Charuluxananan S, Werawatganon T, Termsombatborworn N, Leelachiewchankul F (2008) Risk factors of perioperative death at a university hospital in Thailand: a registry of 50,409 anesthetics. Asian Biomed 2: 51-58.

24. Oyelese Y, Smullian J (2006) Placenta previa, placenta accrete, and vasa previa. Obstet Gynecol 107(4): 927-941.

25. Shibata K, Yamamoto Y, Murakami S (1989) Effects of epidural anesthesia on cardiovascular responses and survival in experimental hemorrhage shock in dogs. Anesthesiology 71(6): 953-959.

\section{Your next submission with Juniper Publishers will reach you the below assets}

- Quality Editorial service

- Swift Peer Review

- Reprints availability

- E-prints Service

- Manuscript Podcast for convenient understanding

- Global attainment for your research

- Manuscript accessibility in different formats

(Pdf, E-pub, Full Text, Audio)

- Unceasing customer service

Track the below URL for one-step submission https://juniperpublishers.com/online-submission.php 